Covered in: ERIH PLUS, CEEOL, Index Copernicus, CrossRef, CrossCheck, J-Gate, Google Scholar, Ideas RePeC, Econpapers, Socionet, KVK, WorldCat.

2020, Volume 8, Issue 2, pages: 28-34 | doi: 10.18662/lumenphs/8.2/43

\section{Some Approaches Regarding the Philosophy of Technology}

\section{Loredana 'T'EREC-VLAD'1}

${ }^{1} \mathrm{PhD}$ in Philosophy, Ștefan cel Mare University of Suceava, Romania, loredana.vlad@,fdsa.usv.ro

\begin{abstract}
The concept of technology can be understood in many ways, especially nowadays, when we are practically connected to a multitude of increasingly complex artifacts. Talking about the philosophy of technology means bringing to the fore a multitude of related fields, as technology has changed the way we behave in the world, the way we relate to others and also the way we think and act.

In this paper we will make an analysis of the concepts of technique and technology starting from the philosophies of Antiquity and continue on the way we currently understand man's relationship with artifacts.
\end{abstract}

Keywords: Philosophy of technology; arts; artifacts; bumans.

How to cite: Terec-Vlad, L. (2020). Some Approaches Regarding the Philosophy of Technology. Logos Universality Mentality Education Novely: Philosophy \& Humanistic Sciences, 8(2), 28-34. doi: https://doi.org/10.18662/lumenphs/8.2/43 


\section{Introduction}

The increased development of technique and technology has determined the rethinking of all actions taken by man and here we mean the way we relate to our peers (Vlad, 2019, Sandu, Terec-Vlad, 2016), the way we perceive motherhood, the relationship with family members (Apostu et al., 2017; Huidu, 2018; Terec-Vlad, 2017) and so forth. The development of technology has changed the values of society, and "despite the fact that the use of artifacts depends upon the needs of the subject, the context and culture in which it occurs, it is important to think about the meaning and significance of technology, the principles and values that allow an ethical use of technology.” (Aguilar-Gordon, 2011).

\section{Prometheus, the fire and the technique}

The human condition presupposes a series of areas that place man in numerous cultural contexts (Pavel, 2016) in the relationship with the other, but also in the relationship with God. The concept of human nature differs from that of human condition. In order to show the relationship between philosophy, technique and technology, we considered it opportune to bring to the fore a series of "founding myths of humanity". For this, we appealed to the myth of Prometheus and the acquisition of fire as a gift for the human kind, an event that led the human being to acquiring capacities or skills for technical production. The Greek myth refers to a Titan named Prometheus who stole fire as a gift for the human kind. This involved human cleverness, on the one hand and art on the other hand (Alonso Salas, 2015). Prometheus' action was punished by Zeus, who ensured everyday that an eagle ate the liver of the Titan as he was helplessly chained to a rock.

In order to understand this myth it is important to comprehend the philanthropic character of the Titan and why he decided to confront the gods in order to provide people with fire. The myth relates that Zeus' intention was to exterminate the human race, but, as a human himself, Prometheus provided them with the science of making fire. In the interpretation of many philosophers, fire stands for technique. The reasons behind this action of Prometheus are the philanthropy and philotechnics, the love for the human race and the hatred he felt towards the gods.

\section{The technique - a philosophical perspective}

A In the Greek mythology, Prometheus is related to the arts derived from fire and he symbolizes the technical function. Regarding this concept, 
in ancient Greek philosophy, the concept of téchnē occupies an important place, along with episteme. The concept of téchnē

is used as a synonym with that of burning (if we refer to the Latin world of ancient Rome) because it was considered that the technique was used to produce an object (be it a horseshoe or a painting). Although the nuances of these terms are multiple, we can limit ourselves to the art and the technique, but their root is approximately the same. From the view point of the Greek philosophers, any person who used craft to produce something opposed nature on the one hand, and science on the other (Aslam, \& Moraru, 2017).

The difference between the two concepts, i.e. téchnē (Platon, 2012, Aristotel, 2010) and episteme is given by the fact that téchnē is learned by practice, while science "is based upon logical deductions and reasoning from certain principles and axioms, which excludes any "error of execution" as long as the reasoning is applied correctly. Aristotle also includes a third concept, that is, phronesis, that is, practical knowledge and practical ethics; the Stagirite refers to values in praxis, the orientation towards action and the ability to think rationally. One of the differences is that between Phronesis and Sophia, in the sense that Sophia involves reasoning about universal truths, while Phronesis requires the ability to think rationally. Although it is obvious that all these three concepts have made a particularly important contribution to philosophy, their explanation will be brief, because we are more interested in man's relationship with technology and how man establishes a connection with technology. As we come back to the ideas captured in ancient philosophy, it is considered that art is a practical knowledge, a skill, a form of mastery in which evolution takes place through repeated cycles of trial, error and correction, while science is a theoretical knowledge, which is eternal and immutable. Therefore, putting together those oppositions by which art is delimited, we notice that the product of téchnē is artificial (which nevertheless must be in a process of harmony with the cosmic order) and "does not originate in a rigorous knowledge based upon deductions and logical reasoning" (Aslam, \& Moraru, 2017). Aristotle and Plato emphasize that téchnē is the knowledge of doing something, but it is necessary to specify that, in terms of art, one can talk about three meanings of the concept of téchnē, from which we highlight: "the process of production or technical knowledge, arts and skill" (Aslam, \& Moraru, 2017). Since in this paper we will bring to the fore the term téchnē, we will explain the understanding of this term by emphasizing the contributions of the most important philosophers. 
In Aristotle's philosophy, the term téchnē is a way of reasoning and is connected to conscious activity based on a method of knowledge, and the term logos is used differently. In addition to the sense of reason given to this term (i.e. logos), it is also understood as "discourse" or "speech", as the Stagirite considers that any type of communication can be achieved through this strategy, given that human weakness uses other persuasive methods (Lohan, 2017, pp. 500-506). However, the concept of logos is used in three fields: in the field of utterance, in the field of thought and in the field of the real (that is, in objects) as this encompasses three categories; the key to the logos is the universality, as it gives "the possibility for the logos to be exercised, thanks to which the logos is possible" (Noica, 1968, p. 104).

If we are to bring to the fore the etymological root of the term technology, we first refer to the Greek logos and the artistic knowledge, that is, the way in which an object that has a specific utility is created. The logos "designates the recourse to reason" (Lohan, 2017, pp. 500-506).

Technology is based on technique. Technology can be understood as the application of scientific knowledge, but nowadays, however, these two concepts are interrelated: technology poses challenges for science and guides new discoveries, and science could not exist without technology.

The technique appears as a result of human activity and as a tool used to achieve and accomplish the goals of the human being. Although the definition implies an instrumental and anthropological approximation, man should not be put in the service of technology, but instead he should direct it according to his goals, as modern technology is closely related to science.

\section{The Heideggerian perspective}

A perspective on the concept of téchnē comes from the Heideggerian course.

The German philosopher emphasizes that "the technique is not the same as the essence of technique" (Heidegger, 1982). In his writings on man's relationship with technology, the idea that nature and humans are seen (from a technological perspective) as a "raw material" for technical operations is key. Heidegger considers that "the technology" has "power of control" over man, and in order to get rid of this possible danger it is necessary to be aware of the risks to which man is subjected. Given his life and his alleged collaboration with the Nazi party, a series of specifications to highlight how the German philosopher saw the relationship of the technique and technology with man are worth noticing. The "essence of technology" is "non-technical", i.e. a way of "revealing the truth" and this relationship must 
be considered to be a free relationship. In his work "The Question Concerning Technology", Heidegger seeks "the essence of technology", but also the relationship that can be established between man and artifacts; the German philosopher believes that it is not necessary to deny or ignore technology. If initially the instrumental definition of technology is rejected because it does not capture the truth in all its complexity, then "the ancient Greek meanings of the four Aristotelian causalities" are drawn, "but they do not seem to capture the essence of technology either."

\section{Understanding the contemporary relationship between man and technology}

Speaking of technology in abstract terms without putting man in this relationship is almost impossible, because the technique/technology has fascinated man since ancient times. It is considered that "we have to understand ourselves today, as we are in the middle of technology, and the technical knowledge in itself cannot help us. The philosophy of technology is related to the self-awareness of a society like ours. It teaches us to reflect on what we take for granted, the rational modernity more precisely. The importance of this perspective cannot be overestimated" (Feenberg, 2006).

Regarding Paul Verbeek's perspective, the use of technology as part of the human body is believed to lead to a human alienation, even if they are seen as an extension of the human body. Moreover, the philosopher speaks of a fusion between man and technology; in this context the physical boundaries are being exceeded because technology merges with the human body. One could say that this could be an immersion relationship, with technology adding an extra layer to the man's experience of the world and opening up an augmentation relationship (Verbeek, 2005). Verbeek deepens the idea of technological mediation in the human action, asking questions with a philosophical substratum regarding the aspects of ethics in the practice of designing technical artifacts. "The technological mediation" is a concept that refers to the way in which artifacts shape the human action. A relevant aspect is related to the fact that in this equation of man and technology, the philosopher quoted above introduces the actor-network theory, developed by Bruno Latour (Latour, 1993). Verbeek reflects upon technology given the ideas of Martin Heidegger and Karl Jaspers, emphasizing that the methodology of the two philosophers rather "goes back", because they try to understand technology metaphysically and do not take into account the role they play in man's daily life. By analyzing the works of Ihde and Latour on the concept of agency, Verbeek develops the 
theory of mediation, making a clear distinction between praxis and hermeneutics and introduces the idea of material aesthetics, a concept that draws attention to how technology mediates the human experience (Verbeek, 2005).

This analysis shows that there must be a relationship between man and machine. The technology continues to shape the way we behave in the world (Vlad, 2019).

\section{Conclusions}

In this paper we have made a brief analysis of the concepts of technique and technology emphasizing the contributions of the philosophers of Antiquity, of Heidegger's, reaching the present day to how Paul Verbeek understands the relationship of man with the technology. We considered it appropriate to bring to the fore these directions of analysis and understanding in order to be able to provide an overview of how technology has changed the way we behave in the world and implicitly to understand the surrounding reality.

\section{References}

Aguilar Gordon, F.R. (2011). Reflexiones filosoficas sobre la tecnologia y sus nuevos escenarios. Sophia: Colleccion de Filosofia de la Educacion, 11, 123-174.

Aguilar Gordon, F.R., \& Chamba Zarango, A.P. (2019). Reflexiones sobre la filosofia de la tecnologia en los procesos educativos. Conrado, 15(70).

Apostu, I., \& Petrescu, C. G. (2017). Bărbatul și femeia: imaginea unei polemici cu privire la echitatea de gen. Lumen.

Aristotel, (2010). Metafizica. Univers Enciclopedic Gold Publishing House.

Aslam, C., \& Moraru, C.F. (2017). Filosofia artei in postmodernitate. Unarte Publishing House.

Feenberg, A. (2006). What Is Philosophy of Technology? In: Dakers J.R. (eds) Defining Technological Literacy. Palgrave Macmillan, New York.

Heidegger, M. (1982). Întrebare privitoare la tehnică, in Originea Operei de Artă. Univers Publishing House.

Huidu, A. (2018). Social acceptance of ethically controversed innovative techniques related to or derived from assisted reproductive technologies-A review of literature. Eastern-European Journal of Medical Humanities and Bioethics, 2(2), 114. https://doi.org/10.18662/eejmhb/11

Latour, B. (1993). We have never been Modern. Harvard University Press, Cambridge. 
Lohan, P.I. (2007). Ethos, Patos, Logos in the Religious Discourse of Father

Cleopa. Jornal of Romanian Literary Studies, 12, 500-506.

Noica, C. (1968). Probleme de logică, Volume I. Academia Publishing House.

Pavel, A. A. (2016). A la decouverte de Paris: leçons de communication interculturelle. Lumen.

Platon, (2012). Theatitetos. Humanitas Publishing House.

Salas, A.A. (2015). De Prometeu a la technociencia. Revista Filosofia, 26, 21-37.

Sandu, A., \& Vlad, L. (2016). A Phenomenological Perspective on Transhumanism from the Perspective of the Spoken of Being. Postmodern Openings, 7(1), 6776.

Vlad L. (2019). Umanism, transumanism, postumanism. Perspective filosofice. Lumen Publishing House.

Vlad, L. (2017). The Family, where to? From the "Solid" Perspective to "Liquid" Perspective. Postmodern Openings, 8(1), 67-80. 